\title{
CORPORATE SELF-DISCLOSURE IN SOCIAL MEDIA
}

Self-disclosure is a well-known phenomenon in interpersonal relationships. The term has also been applied by previous research to corporate-consumer relations, but there are some differences between the two concepts. This paper tries to find a common ground, offers a new definition for corporate self-disclosure (one that is in line with the previous terminology but is closer to the interpersonal approach) and by the means of qualitative research it investigates its possible use in corporate-to-consumer communication. The author also argues that social media is very suitable field for corporate self-disclosure.

Keywords: branding, self-disclosure, social media

$\mathrm{R}$ ecent years have seen a rise in interest in brand to consumer communication. With the emergence of social networks companies that traditionally had little or no communicational contact with their consumers found themselves in a position where they had almost no choice but to start communicating. Research shows that in social media rules are very much different than those in the traditional media. Weineberg (2009) argues that transparency is expected and altruism is the new norm. This requires a very different approach than traditional (mass) media. This paper shows that while self-disclosure is widely accepted to be a foundation of enhancing interpersonal relationships, it is used only in a very limited sense when talking about corporate-to-consumer communication (mainly used by CSR literature to describe content of corporate self-reports that barely ever make to the consumers).

Traditionally, branding has been led by a manager who was in total control of the whole communication process focusing exclusively on the positive and suppressing alternate perceptions (Weston, 2013). Christodoulides (2009) criticized this practice as one displaying the characteristics of those of a "narcissist". With the rise of the internet an especially social media current branding practices focus more and more on concepts like transparency, building relationship with the consumers. Further research in this area might help companies who still experience significant trouble coping with the changed landscape.

This research suggests that "self-disclosure" (which is well-known in psychology literature and have been applied to interpersonal relationships for decades now) might offer considerable help in navigating under these new circumstances. The current paper starts with discussing how the term has been used for interpersonal relationships than it shows that although much less intensively and in a slightly different meaning it has also been used to describe corporate communication mainly in CSR literature.

In the second part findings of an explorative research is presented that (1) helped shaping the definition for this phenomenon (self-disclosure in corporate-to-consumer relations), (2) offered an overview of possible gains and pitfalls of corporate self-disclosure. Managerial implica- tions and suggestions for possible future research directions are offered in the closing section.

\section{Literature review}

\section{Self-disclosure and self-representation}

There has been a growing research interest in self-disclosure and self-representation in online environment ever since internet started its massive growth in the 90's. In the early stages the main areas of such researches were websites, followed by online support groups, forums and multiplayer or massively multiplayer online (MMO) games and even dating sites (Gibbs et al., 2007). After the rapid expansion of social media applications more and more research focused on social network sites (SNS) where people could easily create their own online presence ("self-representation") and were naturally encouraged to participate in self-disclosure.

In this section a brief overview is offered of (1) how psychological literature defines and describes these two concepts and (2) what antecedent and consequences are associated with them - before moving on to investigating the particular phenomenon of self-disclosure and self-representation on SNSs.

Journard interprets self-disclosure as some kind of 'personal transparency' - "yourself manifest, showing yourself so others can perceive you" (Journard, 1971, p. 19). This is a natural phenomenon that takes place whenever people meet with each other. By merely standing in another person's presence one reveals multiple chunks of information (visible traits like sex, approximate age and weight - but often also more personal things like the current mood, etc.). The information shared usually gets deeper and deeper with more personal encounters. People share information about themselves in both verbal and non-verbal way. In literature self-disclosure is usually synonymous with verbal disclosure. Self-disclosure plays a vital role in human interactions. It is a defining characteristic of intimate relationships (Brehm et al., 2002), some researchers even argue that it is the most important process in relationship development (Harvey - Omarzu, 
1997). But it is not limited to intimate relations, from business partnerships to workplace affiliation it plays central role in all sorts of relationships.

Revealing information about self is multiple-staged process. Social penetration theory argued that while usually in the initial stages of a relationship only basic information is shared between the partners (like name, hometown, hobbies, etc.). But as the relationship grows mature, deeper - more intimate, sensitive and emotional - information would be exchanged (Altman -Taylor, 1973). Therefore McCarthy (2009) made a distinction between self-disclosure and self-description: the latter being a more formal phenomenon that only describes less personal information.

Self-disclosure plays vital role in relationships - both in bonding and maintaining personal and/or other types of relations. People engage in self-disclosure in a variety of ways in every relationship they have though the content and the degree of self-disclosure may vary in each of those. To be able to measure self-disclosure Altman and Taylor proposed it to have three dimensions:

1. Breadth: the amount of information exchanged. One can make a distinction on the number of different categories self-disclosure contains ("breadth category") and the breadth frequency that is the number of all different "items" within one breadth category.

2. Depth refers to the intimacy-level of the information exchanged.

3. Duration is the length of time self-disclosure occurs within an interaction (Altman - Taylor, 1973).

Self-disclosure is "rare resource" in the sense that it has significant and positive impact on the relationship to be selected as a recipient of a (perceived) scarce message (Archer-Cook, 1986). Some researchers state that the value of self-disclosure is based on its scarce nature. People might react more positively if they perceive the received information to be more intimate. (Even marketing utilizes this positive correlation when certain corporations (usually luxury brands) disclose information like new products, limited editions, etc. to a preselected group of consumers only who in exchange value this as special, distinguishing treatment.)

Consider the following statements: "I finished high school" and "I love you". It is obvious that the latter "information" is more intimate, but there are other key differences too. The first one is a describing the other is an evaluating type of self-disclosure. The first one simply states a factual information, the second reveals some sort of personal opinion. According to Altman and Taylor (1974) self-disclosure might convey (1) cognitive, (2) emotional or (3) behavioral information.

Research has shown a number of consequences of self-disclosure. Intimacy is closely related to particular types of self-disclosure in both computer mediated and face-to-face communication. Collins - Miller (1994) enumerates three possible different types of connection between liking and self-disclosure:
1. people might like more those who disclose to them more,

2. people might disclose more to people whom they like,

3. people might like others as a result of disclosing to them.

Another relational outcome of self-disclosure is trust. Multiple studies verified the correlation between trust and both the breadth and depth of self-disclosure. This is true in online context, and interestingly online self-disclosure is found to be able to build "offline" trust: Mazera et al. (2009) states that teachers, who exhibit higher levels of self-disclosure on Facebook are found to be more credible by students.

Tokic and Pecnik (2011) found that self-disclosure serves three key functions in adolescents' relationship with their parents: (1) promoting intimacy, (2) regulating autonomy and (3) heightening individuation.

Self-representation is a very similar phenomenon. It is generally defined as "a behavior that attempts to convey information about oneself - or an image of oneself - to others" (Baumeister - Hutton, 1987). There are two types and motivations of self-presentation: (1) presentation meant to match one's own self-image and (2) presentation meant to match audience expectations and preferences. There are notable differences in online and offline types of self-representation largely due to the controlled nature of online media:

1. There is a greater emphasis on verbal and textural elements of communication in online environment. This enables a greater control in comparison with face-to-face communication where non-verbal elements might become dominant (these are harder the keep under control).

2 . The contact is usually made in an asynchronous manner that again enables parties engaged in the communication to send thoughtful, well-constructed messages (Gibbs et al., 2007).

\section{Self-disclosure and self-representation in online context}

Both self-disclosure and self-representation seems to be essential in SNS research. Both have been used before in literature to describe user behavior in social media. One of the most commonly accepted definition and classification of SNSs include "social processes" (self-disclosure and self-presentation) as two key elements of social space (Kaplan - Haenlein, 2010). But even before social media emerged people used personal websites to present themselves in cyberspace. Generally speaking there are several distinctive features of online environment that affects self-disclosure as shown in the Table 1.

According to Kilian (2013) SNSs are personal forums where users tend to share deeply personal even sensitive or intimate information with friends or the general public. The nature of the online media makes it feasible for users to carefully craft the messages or chunks of information 
to be shared. This applies to both personal and corporate users. Research also shows that self-disclosure helps maintaining relationships in online context.

Distinctive characteristics of face-to-face selfdisclosure and self-disclosure in computer mediated communication

\begin{tabular}{|c|c|c|}
\hline & $\begin{array}{c}\text { Face-to-face } \\
\text { (FTF) } \\
\text { self-disclosure }\end{array}$ & $\begin{array}{c}\text { Self-disclosure in } \\
\text { computer mediat- } \\
\text { ed communication } \\
\text { (CMC) }\end{array}$ \\
\hline $\begin{array}{c}\text { (Percieved) ano- } \\
\text { nymity }\end{array}$ & Low & High \\
\hline Visual cues & High & Low/missing \\
\hline Physical distance & Low & Unknown/high \\
\hline $\begin{array}{c}\text { Control of conver- } \\
\text { sation }\end{array}$ & Generally low & Higher \\
\hline $\begin{array}{c}\text { Pace of conversa- } \\
\text { tion }\end{array}$ & Faster & Usually slower \\
\hline $\begin{array}{c}\text { Number of partic- } \\
\text { ipants }\end{array}$ & $\begin{array}{c}\text { Mostly two / lim- } \\
\text { ited }\end{array}$ & $\begin{array}{c}\text { Two (private chat) } \\
\text { or unlimited (public } \\
\text { posts) }\end{array}$ \\
\hline $\begin{array}{c}\text { Reciprocity of } \\
\text { self-disclosure }\end{array}$ & $\begin{array}{c}\text { Usually expected } \\
\text { May or may not be } \\
\text { expected (eg. with } \\
\text { public posts) }\end{array}$ \\
\hline \multicolumn{2}{|c|}{ Source: Literature review conducted by author }
\end{tabular}

Another important and interesting aspect of online self-representation is that people/corporations engage in information sharing with different types of interest groups at the same time. When discussing interpersonal relationships this means that users share information about themselves to groups that they would otherwise handle in a very distinct manner. For instance, sharing party pictures with friends is nothing uncommon - but when looking for new carrier opportunities one would definitely not want a possible future employer to see those images.

This issue is not new in a sense that it is a well-documented fact in literature that while basic personality characteristics are consistent over time individuals might choose to play different roles for a given audience (Arnett et al., 2003) - these roles even might explicitly be in conflict with one another. Heide and Wathne for example (2006) focusing on relationship roles of friends and businesspeople in marketing showed that as a "friend," one uses a "logic of appropriateness" will follow established rules, while as a "businessperson," the same person's decisions are guided by utility-maximizing considerations under a "logic of consequences".

But in online context the nature of social media makes an important difference: in SNS context switching between roles might prove difficult. As one's network grows in numbers and diversity it might require a considerable amount of effort to choose information to be shared. The situation is even more complex as the network primarily consists of people with whom the user also maintains offline relationship - therefore the user is sensitive to the audience's opinion of the items shared in social media. Killian (2013) argues that one way to cope with this challenge is for users to try to exhibit an idealized self-image in SNSs. They can also opt to avoid/or keep sensitive topics to a minimum.

To have a better understanding of how users share personal information in SNS context two new psychological concepts are needed to be investigated: self-regulation and self-control. "Self-regulation is the broader term, encompassing both conscious and unconscious processes and sometimes referring to all behavior guided by goals or standards, whereas self-control refers more narrowly to conscious efforts to alter behavior, especially restraining impulses and resisting temptations" (Baumester, 2002, p. 129.). The individual capability to apply self-regulation varies greatly among people. It is thought to be a depletable resource.

Self-regulation has been shown to affect profoundly user behavioral pattern in SNS context. Users with greater ability to perform self-regulation use SNS platforms in a more focused manner and are more efficient in creating and consuming content. Emotions play a smaller role in their use of SNS applications: they seek expediency (Rouis et al., 2011).

\section{Proposing the concept of corporate self-disclosure}

The previous section demonstrated that self-disclosure is an important factor influencing the creation and maintaining of personal relationship in both face-to-face (FTF) and computer mediated context (CMC). Revealing intimate and personal information about self helps strengthen and deepen interpersonal relationships. The question that arises: can we detect self-disclosure in corporate (brand) - consumer relations?

The question is not as far-fetched as it might seem. First, there is a large and growing literature on the anthropomorphizing of brands which is defined as "the belief that consumers tend to perceive branded products as if these objects were humans" (Guido - Peluso, 2015). Tamasits - Prónay (2018) argued that consumers might display emotions toward brands similar to those seen in interpersonal relationships. Brand managers have been shown to encourage anthropomorphizing in several ways from product design to naming and promotion. Several brands try to exploit this in a variety of ways like using anthropomorphism to make their brand more memorable and exciting, to strengthen existing brand associations or simply to make the brand more likeable.

This tendency also deeply affects the two-way communication between consumers and brands (Markos-Kujbus, 2016). In this new context brands elicit effects previously seen for responses to people (Aggarwal - McGill, 2011). More studies showed that people might form relationships with brands that are similar to interpersonal ones (Guido - Peluso, 2015).

The second argument for self-disclosure in corporate - consumer relations is the fact that in CSR literature there are a handful of research that builds on corporate self-disclosure in a very specific way. According to recent researches one main problem in evaluating any firm's 
corporate social responsibility is that the source of most data available on the topic is the firm's self-disclosure like company and stakeholder self-reports (Font et al., 2012). This obviously affects measurement reliability, validity, etc. but for us it also sheds light on the fact that companies do use self-disclosure in their communication activities. The term "self-disclosure" or "corporate self-disclosure" is used in this sense and refers almost exclusively to CSR, social self-reports and other documents. These - while they undoubtedly form a crucial part of corporate communication - barely reach consumers en masse.

A third and closing argument comes from the field of services marketing. Regarding the operations of a company, Greyson (1998) makes a distinction of three separate "stages":

- frontstage: operations and workspace customers perceive to be created for them to have access to,

- backstage: operations and workspace customers have no access to,

- perceived backstage: operations and workspace that customers perceive they shouldn't have access to (but they do).

Creating a "perceived backstage" can be understood as one type of corporate self-disclosure where the organization tries to create the illusion of sharing something unique or "intimate" with the consumer.

Other than all those reasons it is a fact that branding has changed profoundly in the (post) internet era. "Postinternet branding is about facilitating conversations around the brand. Consumers are now wired and capitalize on social networks to derive power from one another. They develop their own perspective on companies and brands, a view that is often in conflict with the image a brand wishes to convey" (Christodoulides, 2009). Weston (2013) argues that companies can survive and thrive the changed landscape by using co-creation as a philosophy for branding through social media. This means a relational approach to branding where the consumer is involved as an equal partner.

\section{Terminology}

Before moving onto describing the research, it is important to discuss terminology. As a conclusion of previous literature review one can argue that there is a phenomenon in brand-to-consumer communication that is very similar in nature to that which is described in psychology literature by the term "self-disclosure". On the other hand: in marketing/CSR literature self-disclosure is used in a slightly different meaning (mainly referring to self-reporting documents that barely reaches ordinary customers). The current paper uses the term self-disclosure in the former sense. An exact definition is offered later on based on research findings.

As in McCarthy (2009) a distinction is made between self-description (formal, less "personal" information about self - this case: company) and self-disclosure (more "intimate" information about self).

\section{Proposed framework and research method}

The current research design used a slightly modified version of the customer-centric model of brand community that was proposed by McAlexander, Scouten and Koenig in their frequently cited article (McAlexander et al., 2002). The reason to choose this model was twofold: first, it incorporates every major factors of brand communication and second, it was extensively used in SNS research (cf. Milán-Díaz, 2014). (Figure 1.)

Figure 1.

Customer-Centric Model of Brand Community Dashed lines are not included in the original model

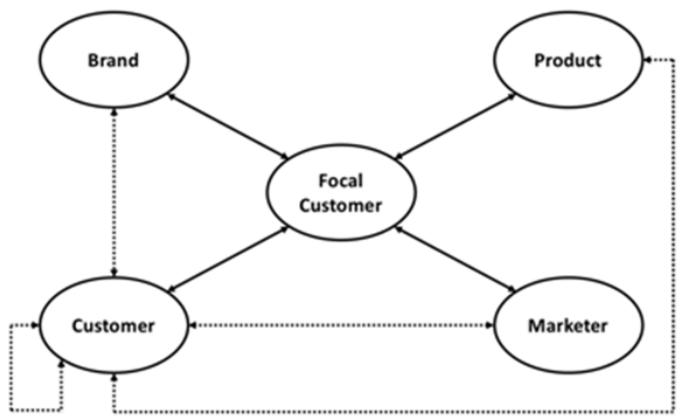

(Source: McAlexander et al., 2002. p. 39.)

This approach assumes that brands (marketers) communicate both directly and indirectly (through focal customers) to customer and similarly customers have direct and indirect contact with products. In line with literature due to the nature of SNSs communication observed among customers is also a distinctive factor.

The main research questions were the following:

RQ1. Is there or what is the an equivalent of "intimate" information seen in interpersonal relations in corporate-to-consumer ones?

Note: all the other research questions posited below become meaningful only if the research reveals that there exist equivalent factors of intimate information in corporate-to-consumer relations.

RQ2. What possible outcomes might have on brands corporate self-disclosure in social media (SNSs)?

Social media seems a natural choice for self-disclosure for companies as they gradually need to assume the role of content providers (Csordás - Gáti, 2014). But this RQ is a long one that includes multiple dimensions in it - so to be able to shed some light on this particular issue the following auxiliary questions were defined:

RQ2a. How can brands benefit from self-disclosure in their relationship with consumers on SNSs?

RQ2b. What are the pitfalls of corporate self-disclosure in their relationship with consumers on SNSs?

RQ3. Of all the possible corporate-consumer relations stated in Figure 1. which can contain elements of self-disclosure that affects the relation in any way? 
All these research questions suggest that this is a new complex phenomenon that requires a holistic approach. Because of these specifications an explorative research was conducted to gain better understanding and so semi-structured focus group interviews were used. The semi-structured nature of the interview refers to the conative approach as described by Malhotra and Birks (2007): the emphasis was on exploration, with analysis taking place during and after the group interviews. There was less structure to the questions, and in both focus groups members were encouraged to take their own paths of discussion, make their own connections and let the whole process evolve.

The objective of this small-sample, non-representative study was to uncover underlying factors and provide understanding of self-disclosure in corporate-to-consumer relationships. Two focus group interviews were conducted, one with 5 and one with 6 respondents. Participants were chosen from an MA class at a business university. (This also meant that while the literature review section focused on both corporate and consumer aspects of self-disclosure the research mainly investigated the consumer side of the phenomenon). The interviews lasted 95 and 104 minutes respectively and were tape recorded with the consent of the respondents for further analysis. During the interviews an assistant moderator created notes that were later clarified and complemented based on the audio recording which resulted in 46 pages of transcripts (not verbatim) (Krueger - Casey, 2002). Partial verbatim transcripts have been created of certain parts of the focus group interviews to enable deeper analysis.

Both focus group interviews started with the moderator briefly covering the objectives and the nature of the study. In the first, much shorter section respondents were asked about self-disclosure in interpersonal relations. This was done to (1) to clarify their understanding of this phenomenon and (2) familiarize them with this issue. Responses made in this sections were generally irrelevant to our study therefor were largely not interpreted during the analysis. In the second, longer section (after they become familiar with research terminology) they were asked about self-disclosure in general in corporate-to-consumer relationship before systematically exploring relationship elements described in Figure 1. In this section respondents were also asked to come up with their own examples of corporate self-disclosure and also to analyze different types of it (the analyzed examples are included in Appendix 1.)

\section{Discussion}

\section{Self-disclosure in corporate-to-consumer relationship}

Respondents were quick to apprehend the gist of terms "self-description" and "self-disclosure" in corporate-to-consumer relations. Self-description was universally accepted by all respondents to be observable in branded communication. It was debated however whether self-disclosure could be applied to relationship outside the context of interpersonal ones. Key differences that emerged in the focus groups are summed up in the Table 2.

Table 2.

\section{Key differences of interpersonal and corporate- to-consumer relationships that could affect corporate self-disclosure}

\begin{tabular}{|c|c|c|}
\hline & Interpersonal & $\begin{array}{c}\text { Corporate-to- } \\
\text { consumer }\end{array}$ \\
\hline Emotions & $\begin{array}{l}\text { All kinds of emotions } \\
\text { are observable }\end{array}$ & $\begin{array}{l}\text { Some respondents } \\
\text { viewed companies as } \\
\text { non-sentient beings } \\
\text { that are unable to } \\
\text { show any emotion }\end{array}$ \\
\hline Trust & $\begin{array}{l}\text { Key element in the } \\
\text { relationship }\end{array}$ & $\begin{array}{l}\text { Might occur but not } \\
\text { dominant }\end{array}$ \\
\hline Relationship & $\begin{array}{l}\text { Honesty or trust } \\
\text { based }\end{array}$ & $\begin{array}{l}\text { Interest based, ma- } \\
\text { nipulative }\end{array}$ \\
\hline Environment & Friendly & $\begin{array}{l}\text { Characterized by } \\
\text { competition }\end{array}$ \\
\hline Intimacy & $\begin{array}{l}\text { Key element in deep } \\
\text { personal relationship }\end{array}$ & Not applicable \\
\hline $\begin{array}{l}\text { Reciprocity } \\
\text { of self-disclo- } \\
\text { sure }\end{array}$ & Possible and frequent & $\begin{array}{l}\text { Some respondents } \\
\text { viewed consumer to } \\
\text { corporation self-dis- } \\
\text { closure as impossible } \\
\text { to exist }\end{array}$ \\
\hline
\end{tabular}

Source: research

A few respondents viewed trust as a central issue that might be distinctive in interpersonal and corporate-to-consumer self-disclosure. One very specific objection was raised in the second focus group: "If we accept that self-disclosure conveys more intimate, personal information about self then it also means that by self-disclosure one - in a sense - becomes vulnerable to the other party. That is why it is able to build trust: one person trusts a valuable personal information to the hands of another person. I can't see a way this would work in corporate communication. Why would a company offer its consumer to know its weakness?" (Male, 28). Later on, this objection was dissolved in group discussion. Respondents agreed that while exposing vulnerability cannot be expected from corporations (due to the competitive nature of the markets) building trust can be achieved by either (1) other types of self-disclosure (as to be seen later) or (2) "exposing" "perceived" vulnerabilities (one that in the eyes of the consumers looks like a vulnerability but in reality, is not). An example mentioned was the Hungarian bank Magnet who - unlike other financial institutions - offers description on how their pricing structure is made up.

Similarly, intimacy has been discussed. "As I come to think of it, much of my own "self-disclosure" really was in connection with sharing intimate information. How could a company share something intimate? Intimacy can only be present in interpersonal relationships" (Female, 25). No interviewee in neither focus groups could point out anything similar to intimacy in corporate-to-consumer communication. 
Finally, another key dimension was discussed: reciprocity. Opinions on this issue were split mainly because a few respondents denied that consumers would disclose self to corporations. However, in defining corporate-to-consumer self-disclosure this is not an issue as (1) unreciprocated self-disclosure might happen in interpersonal relationships too and (2) other respondents showed examples that in fact it might happen. "Browsing the web, using Facebook - everybody exposes very deep, intimate information to not only these companies - Google, Facebook, etc. - but to those also, who buy consumer data from them" (Male 25).

In the focus groups participants were asked to describe their latest act of self-disclosure and the emotions they associate to it. Later on, they were shown a few examples of what were deemed to be examples of corporate self-disclosure (see Appendix A.) and again they were asked to describe their feelings and any thought they associate to these corporate messages. The answers received were transcribed (verbatim) and a word cloud was generated based on the most frequently used words in both cases. (Figure 2.)

Figure 2.

Word clouds of the most frequently used words to describe personal experiences on self-disclosure (left) and examples of corporate self-disclosure (right). The size of the word indicates frequency of occurrence
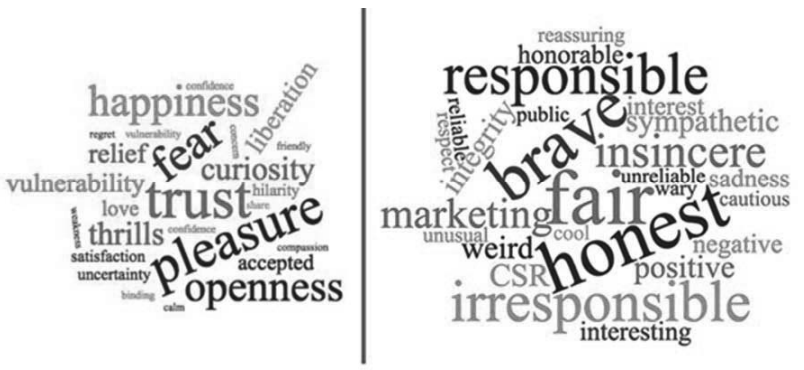

Source: research

The similarities are obvious, but there are differences too:

- in personal self-disclosure there were very vivid descriptions of uncertainty even feelings of vulnerability that was completely missing in its corporate equivalent,

- personal self-disclosure is deeply connected to emotions while corporate self-disclosure (when trusted upon) is seen as something "brave", "responsible" and "honest",

- multiple respondents expressed distrust of various forms and intensity for corporate self-disclosure.

Both focus groups concluded that both self-description and self-disclosure is observable in corporate-to-consumer relations. Not every company does it and not to everyone, but it is definitely a phenomenon that is worth further investigation.

\section{Definition and key elements of corporate self-disclosure}

\section{Suggested definition of corporate self-disclosure}

Based on literature review and primary research the following definition is suggested: corporate self-disclosure is the voluntary act of sharing internal information to any stakeholders (but primarily to the consumers) through a media that is most likely to reach the affected stakeholder or group of stakeholders.

Respondents agreed that one key dimension of corporate self-disclosure is voluntarity. In this sense the meaning of "self-" is twofold: it refers to (1) the internal nature of the information revealed (i.e. it says something about the company itself) and (2) the motivation to reveal it is also internal (and not because of legal or governmental pressure, fact-finding journalists, etc.). One participant summed it up: "revealing some information for the fearing of legal consequences is like confessing something personal only because somebody is holding a gun to your head. It is really not self-disclosure rather forced-disclosure" (Female 23).

Next the medium used for delivering corporate self-disclosure message was discussed. Respondents were first asked to evaluate a product recall message where a well-known retailer recalled a hair clipper product line for safety reasons (they found the clipper could catch fire or even explode posing serious threat to life). The message emphasized that it was the company's own decision to do so, as there was no external pressure in this case. The message was published online via the company's website and later received some press coverage (one newspaper article was shown to the participants).

Reactions of the interviewees were largely positive: "It is absolutely positive that the company is capable of admitting its own mistakes", "it was the honorable thing to do", "it improves my overall opinion of the company".

Next the company's Facebook page (with 713.000 likers) were also shown on, before and after the day when the product recall was made. The company made no public Facebook post about the recall of the hair clippers. This fact immediately changed the respondents' mood and opinion. Many comments accused the company with manipulation and being unfair to its consumers: "this is no fair to the consumers, seems they are afraid of negative changes to their reputation", "this is manipulation at its worst", "first I thought they are very responsible to reveal this sensitive information to the public, but now I see they are really not interested in really reaching the consumers. They want to protect their own image more than the lives of their consumers".

From all this one can draw the conclusion that it is not enough for a company to be honest - they have to do it in a way that reaches its consumers. This is in direct contrast with the definition of self-disclosure in CSR literature where it mostly refers to self-reports and other documents that barely ever reach the actual customers. "The medium is the message" (McLuhan, 1964).

Finally, the "internal" nature of the information conveyed in self-disclosure was also investigated. Respondents 
were presented with a Facebook post of a Hungarian bank that conveyed information on the reason for the pricing of a certain account package. This information is rarely made public opinions split on this issue. Some argued that this is an honest, creative and self-revealing message. "This is a consumer-friendly solution, one that is very fair and honest. It is courageous, cool and innovative" (Female, 22). Others debated the fairness and called it a marketing scam - but even most of them acknowledged that it might be powerful to convince other consumers. "I can't believe that it is so, it's only marketing. But it might be able to create the impression of being a transparent bank" (Male, 24).

To better understand where consumers expect (or at least hold credible) corporate self-disclosure the model shown in Figure 1. was used. (Table 3.)

Table 3.

\section{Consumers' expectations regarding corporate self-disclosure}

\begin{tabular}{|c|c|c|}
\hline $\begin{array}{c}\text { Type of } \\
\text { interaction }\end{array}$ & $\begin{array}{l}\text { Can it be affect- } \\
\text { ed by corporate } \\
\text { self-disclosure? }\end{array}$ & $\begin{array}{l}\text { Examples of possible cor- } \\
\text { porate self-disclosure }\end{array}$ \\
\hline $\begin{array}{l}\text { Brand - } \\
\text { consumer }\end{array}$ & Yes & $\begin{array}{l}\text { Revealing hidden infor- } \\
\text { mation on the brand to the } \\
\text { consumer } \\
\text { Inviting consumers to a } \\
\text { "behind the scenes" tour } \\
\text { (virtual or real) }\end{array}$ \\
\hline $\begin{array}{l}\text { Consumer - } \\
\text { consumer }\end{array}$ & Yes & $\begin{array}{l}\text { eWoM, consumers discuss- } \\
\text { ing corporate messages }\end{array}$ \\
\hline $\begin{array}{l}\text { Product - } \\
\text { consumer }\end{array}$ & Yes & $\begin{array}{l}\text { Revealing otherwise hid- } \\
\text { den information on the } \\
\text { product (eg. pricing struc- } \\
\text { ture) } \\
\text { Revealing information } \\
\text { damaging to corporate } \\
\text { image (eg. product mal- } \\
\text { functioning or recall) }\end{array}$ \\
\hline $\begin{array}{l}\text { Marketer - } \\
\text { consumer }\end{array}$ & No & e \\
\hline
\end{tabular}

Source: research

\section{Goals (possible benefits) \\ of self-disclosure on social media}

According to Ignatius - Kokkonen (2007) the following types of information might be revealed in interpersonal self-disclosure: thoughts, feelings, aspirations, goals, failures, successes, fears, and dreams, as well as one's likes, dislikes, and favorites. But what can a company achieve by revealing otherwise hidden information to the general public, selected consumers or a group of consumers? In the previous section of this paper three possible examples of corporate self-disclosure were described. These were also presented to the respondents of the focus groups. By analyzing their reactions their answers were grouped into possible benefit categories:
- enhancing consumer involvement: respondents used wording like "pride", "sympathy", "cool", etc. that indicate that their involvement with these brands,

- enhancing brand value: multiple interviewee reported an overall positive emotional change in their attitude towards the brand after being exposed to corporate self-disclosure,

- enhanced eWom: consumers found corporate self-disclosure messages to be interesting and therefore might have a positive impact on the volume and orientation of consumer-to-consumer talks on the brand,

- self-revealing inconvenient truth or mistakes might leave the company in control of the events that unfold. If the company is the first to publish report on its own error media and government have less room for maneuvers.

\section{Threats (possible pitfalls) \\ of self-disclosure on social media}

Using the method described above multiple threats of corporate self-disclosure were uncovered. One obvious threat is damaging corporate and brand image by revealing errors, mistakes. It might even have a multiplicator effect. One respondent said after reading about the "whale incident" of Maersk: "They just might as well trying to protect themselves of possible fall out, or I can even imagine that they are covering up for something even bigger. What if the whale was in deed alive and the captain in fact did nothing to avert collision? By coming out first with the story they had control over the message and prevented finding themselves in a defending position" (Male, 24). This indicates that by telling the truth some consumers might feel that they are being fed only half-truth and the company still has things to hide.

It might help the forming of negative emotional or cognitive bonds. A remarkable proportion of the words used in connection with the afore mentioned examples of corporate self-disclosure were extremely negative, ones that companies would be at pains to steer clear of.

Revealing unfavorable product information might damage sales. "I instantly become worried if we purchased that item. Also, in the future I might think twice before buying electronic merchandise at this shop" (Female, 23). The shop in question is not a professional electronics manufacturer but it does distribute consumer electronic devices under its own private label. As consumers do not view this shop as an expert in manufacturing, revealing information on product malfunction might have a greater negative impact.

While considering the downsides to self-disclosure in certain situations managers have to give thought to considering the threats of trying to cover up inconvenient circumstances. This might have its own serious consequences.

\section{Managerial implications}

Current research shows the need for further changes in corporate-to-consumer communication. The literature review section of this paper referred to self-disclosure 
in a parent-child relationship. One interesting aspect of well-functioning relationships of this kind is that self-disclosure starts to affect deeper layers of the personality as the child grows mature. When doing everything to cover up every little failure or even mistakes of the company to show an immaculate, sparkling clean image what the managers are doing really is treating their consumers as if (1) they're unable to process negative information and (2) they will immediately turn their backs on the corporation if they see imperfections.

Will honesty pay off in the long run? It's a tough question not easy to answer. The current research had the serious limitation of excluding competition and competitors in the examination. It is possible that revealing weakness or internal information could seriously damage the company's legitimate self-interest. But it is arguable that revealing imperfections, mistakes or information that would normally would remain a company secret (like pricing structure of a financial institute) might have and opposite effect and enhance the relationship of the corporation and its consumers.

Both literature and current research suggest that social media is the right medium for corporate self-disclosure. There are numerous reasons for that. Communication on SNSs is more open and honest, transparency is the norm, fallibility is not only pardonable but sometimes it seems to be even desirable (Weinberg, 2009). Also it is capable of reaching much more consumers than corporate websites.

Finally: every aspect of self-disclosure needs to be carefully designed. Threats are very real. Consumers might even feel deceived if they anticipate that the company is not $100 \%$ honest or uses tricks on them (eg. publishing on low traffic websites to avert attention). Much thought needs to be given to the selecting of the communications channel and target group(s), wording of the message, timing and other factors.

\section{Limitations and possible further research directions}

In the closing section limitations of current research is discussed and further research directions are offered. There were little room to expound the well-known limitations associated with qualitative research. The research framework did miss many important factors including the following ones:

- It didn't take the dynamics of the relationship into account. The possible consequences of corporate self-disclosure might be quite different if the consumer has little or no knowledge of the firm or if the consumer has long been familiar with it.

- It solely focused on the relationship of the corporation and the consumer. It is obvious that this relation exists in its own environment - one that is characterized by the actions of such stakeholders like government/legislation or competitors.

Due to the explorative nature of the current research possible benefits and pitfalls were covered but did not discuss how to exploit/avert them. This is a hot issue that might be a topic of a future research. Given the nature of corporate self-disclosure such a research might help a great deal in understanding this phenomenon.

In this paper there were no room to discuss consumers' self-disclosure to corporations. Literature shows there is another direction for research and that the personal self-disclosure of people might include branded content (eg. defending loved brands in SNSs in personal discursions). This (consumer to corporation) type of self-disclosure might raise serious privacy issues as more research (eg. Simay - Gáti, 2017) shows that consumers are becoming increasingly more concerned about their personal data handed over to companies.

\section{References}

Aggarwal, P. - McGill, A. L. (2011): When brands seem human, do humans act like brands? Automatic behavioral priming effects of brand anthropomorphism. Journal of Consumer Research, 39(2), p. 307-323. https://doi.org/10.1086/662614

Altman, I. - Taylor, D. (1973): Social penetration theory. New York: Holt, Rinehart \& Manston

Archer, R. L. - Cook, C. E. (1986): Personalistic selfdisclosure and attraction: Basis for relationship or scarce resource. Social Psychology Quarterly, p. 268272. https://doi.org/10.2307/2786809

Arnett, D. B. - German, S. D. - Hunt, S. D. (2003): The identity salience model of relationship marketing success: The case of nonprofit marketing. Journal of Marketing, 67(2), p. 89-105. https://doi.org/10.1509/ jmkg.67.2.89.18614

Baumeister, R. F. (2002): Ego depletion and self-control failure: An energy model of the self's executive function. Self and Identity, 1(2), p. 129-136. https://doi. org/10.1080/152988602317319302

Baumeister, R. F. - Hutton, D. G. (1987): Selfpresentation theory: Self-construction and audience pleasing. In: Theories of group behavior. New York, NY: Springer, p. 71-87. https://doi. org/10.1007/978-1-4612-4634-3_4

Brehm, S. S. - Miller, R. S. - Perlman, D. - Campbell, S. (2002): Intimate Relationship. Boston: McGraw-Hill

Christodoulides, G. (2009): Branding in the post-internet era. Marketing Theory, 9(1), p. 141-144. https://doi. org/10.1177/1470593108100071

Collins, N.L.-Miller, L.C.(1994): Self-disclosureandliking: a meta-analytic review. Psychological Bulletin, 116(3), p. 457. https://doi.org/10.1037/0033-2909.116.3.457

Csordás, T. - Gáti, M. (2014): The New (Marketing) Role of Firms as Media Content Providers - The case of SME's Strategic Social Media Presence. Vezetéstudomány/ Budapest Management Review, 45(2), p. 22-32.

Font, X. - Walmsley, A. - Cogotti, S. - McCombes, L. Häusler, N. (2012): Corporate social responsibility: The disclosure-performance gap. Tourism Management, 33(6), p. 1544-1553. https://doi.org/10.1016/j. tourman.2012.02.012 
Gibbs, J. L. - Ellison, N. B. - Heino, R. D. (2006): Self-presentation in online personals: The role of anticipated future interaction, self-disclosure, and perceived success in Internet dating. Communication Research, 33(2), p. 152-177. https:// doi.org/10.1177/0093650205285368

Grayson, K. (1998): Customer responses to emotional labour in discrete and relational service exchange. International Journal of Service Industry Management, 9(2), p. 126-154. https://doi. org/10.1108/09564239810210488

Guido, G.-Peluso, A.M. (2015): Brand anthropomorphism: Conceptualization, measurement, and impact on brand personality and loyalty. Journal of Brand Management, 22(1), p. 1-19. https://doi.org/10.1057/bm.2014.40

Harvey, J. H. - Omarzu, J. (1997): Minding the close relationship. Personality and Social Psychology Review, 1(3), p. 224-240. https://doi.org/10.1207/ s15327957pspr0103_3

Hassan, M. - Mydock, S. - Pervan, S. J. - Kortt, M. (2016): Facebook, self-disclosure, and brand-mediated intimacy: Identifying value creating behaviors. Journal of Consumer Behaviour, 15(6), p. 493-502. https://doi. org/10.1002/cb.1586

Heide, J. B. - Wathne, K. H. (2006): Friends, businesspeople, and relationship roles: A conceptual framework and a research agenda. Journal of Marketing, 70(3), p. 90103. https://doi.org/10.1509/jmkg.70.3.90

Ignatius, E. - Kokkonen, M. (2007): Factors contributing to verbal self-disclosure. Nordic Psychology, 59(4), p. 362-391. https://doi. org/10.1027/1901-2276.59.4.362

Jourard, S. M. (1971): Self-disclosure: An experimental analysis of the transparent self.

Kaplan, A. M. - Haenlein, M. (2010): Users of the world, unite! The challenges and opportunities of Social Media. Business Horizons, 53(1), p. 59-68. https://doi. org/10.1016/j.bushor.2009.09.003

Killian, V. A. (2013): Three Perspectives of Relationships in a Social Media Context: Managing Self-presentation, Evaluating Brand Communication Effectiveness, and Guidelines for Managers. Doctoral dissertation. University of Georgia

Krueger, R. A. - Casey, M. A. (2002): Designing and conducting focus group interviews.
Malhotra, N. - Birks, D. F. (2007): Marketing Research: An Applied Approach. 3rd European ed. Harlow: FT Prentice Hall, Financial Times. https://doi.org/10.1108/ S1548-6435(2007)3

Markos-Kujbus, É.(2016): Azon-lineszájreklám(electronic word-of-mouth) jellemzői a marketingkommunikáció szempontjából. Vezetéstudomány/Budapest Management Review, 47(6), p. 52-63.

McAlexander, J. H. - Schouten, J. W. - Koenig, $H$. F. (2002): Building brand community. Journal of Marketing, 66(1), p. 38-54. https://doi.org/10.1509/ jmkg.66.1.38.18451

McCarthy, A. (2009): Social penetration theory, social networking and Facebook. Fairfield University, p. 1-26.

McLuhan, M. (1964): Understandig media. The Extensions of Man. New York

Milán, Á. - Díaz, E. (2014): Analysis of consumers' response to brand community integration and brand identification. Journal of Brand Management, 21(3), p. 254-272. https://doi.org/10.1057/bm.2014.4

Nguyen, M. - Bin, Y. S. - Campbell, A. (2012): Comparing online and offline self-disclosure: A systematic review. Cyberpsychology, Behavior, and Social Networking, 15(2), p. 103-111. https://doi.org/10.1089/cyber.2011.0277

Rouis, S. - Limayem, M. - Salehi-Sangari, E. (2011): Impact of Facebook usage on students' academic achievement: Role of self-regulation and trust. Electronic Journal of Research in Educational Psychology, 9(3), p. 961-994.

Simay, A. E. - Gáti, M. (2017): A fogyasztói jelenlét és a nyilvánosság iránti attitüdök vizsgálata a mobil és közösségi médiában. Vezetéstudomány/Budapest Management Review, 48(1), 61-69. https://doi. org/10.14267/VEZTUD.2017.01.06

Tamasits, D. - Prónay, S. (2018): A fogyasztó és a márka közötti viszony új dimenziói. Vezetéstudomány/ Budapest Management Review, 49(3), p. 11-18. https://doi.org/10.14267/VEZTUD.2018.03.02

Tokić, A. - Pećnik, N. (2011): Parental behaviors related to adolescents' self-disclosure: Adolescents' views. Journal of Social and Personal Relationships, 28(2), p. 201-222. https://doi.org/10.1177/0265407510382320

Weinberg, T. (2009): The new community rules: Marketing on the social web. Sebastopol, CA: O'Reilly

Weston, S. M. (2013): The social brand. Doctoral dissertation. Auckland University of Technology 


\section{A. Appendix 1. \\ Examples of corporate self-disclosure used in research}

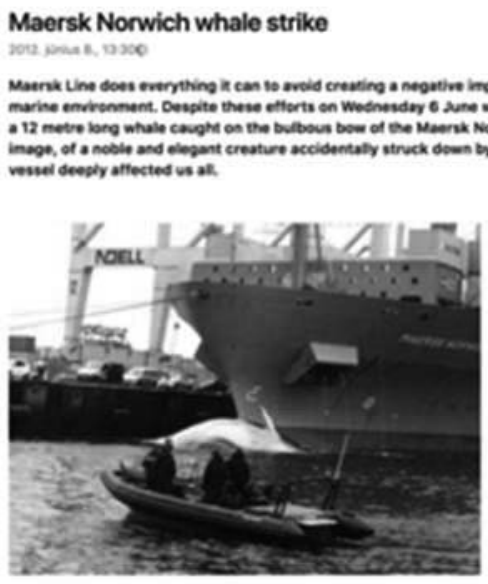

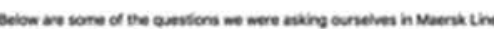

What napeened ather the whulo artived in ports

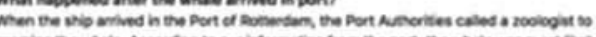

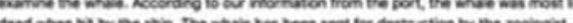

What do $\rightarrow \rightarrow$ do in peneral to mois straing wholest

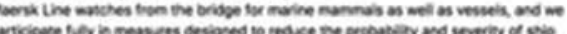
strats.
In the US, we slow to less than 10 knots in designated zones, as defhed by National

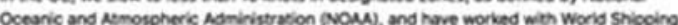
Canncil (WSC) and NOMU to heve radar seeed data provided to each shiboing ine to prevent these incisents from octuring

We are working to betier understand the science related to whale behwiours and how to reouce the probebilify of hitting marine mammals. We are members of the World Ocen Caunol and continve to meet with NOMA and others concerned with marke mammals.

Does the fact that we are slow steuming make a difference? Yes, a does. According to NOM slower speeds reduce likelinood of injury or fotwily when a strike does ocou.

What are the regulations on this, and does Moersk Line comply with them? The NOM fact sheet on the US speed reduction zones states - and me comply with in Chat vessels are to tranet at less than 10 knots in devionated areas, which cover aimost at Netortic ports from November to April each yes. There ave also oynaric voluntary speed recuction areas - aierts to vesseis inhen groups of wholes are spotted in a particular. location.

Ne verst ine, me track wersel soped complance entrs carefuly ouring the seusons when wholes are acely to be present.

How does Maersk Line protect the oceans, mildite a bicoiversity whars you sustainability strategy on this areas?

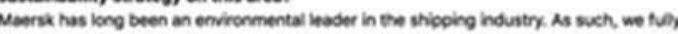

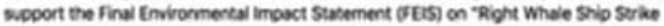
peduction" as we wish to helo bis endangered species repepulate the ocesns.

Nanrsk Line and Maenk the tid. are members of the World Shipping Councl (WSC) and neve worked clotely with wSC througtout the developmert de bee fis and proposed Nes. We have copenty ghared our experiences with both wsC and with Noul including

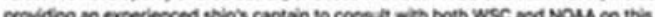
iseve.

\section{Robbanásveszélyes termékre figyelmeztet a Lidl

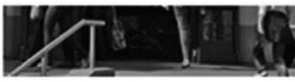

Vaskor Máté

ÚJSÁGíRó. 2018. 03.26. 17:02
(9) 2 (118
A fogyasztók biztonsága érdekében a TARGA GmbH visszahívja a Silvercrest Haj- és szakállvágó SHBV $800 \mathrm{Al}$ termékét. A visszahivásban érintett termék hátoldalán a 290952-es cikkszám található, olvasható a cég honlapján.

A visszahivás oka, hogy az esetlegesen hibásan gyártott készülék töltés és használat során kigyulladhat és szétrobbanhat. A TARGA GmbH ezért arra kéri a vásárlókat, ne használjajk tovább a terméket.
MagNet Bank

2017. június 21. - C

Mennyit ér meg Neked havonta a bankszámlád?

Osztottunk, szoroztunk, és kiszámoltuk, hogy nekünk önköltségi áron 383 forintba kerül egy lakossági számla fenntartása.

Sok? Kevés? Megadod? Többet is megér Neked?

A MagNetnél ezt teljesen Rád bízzuk, és becsületkassza alapon eldöntheted, mennyit fizetsz érte havonta 0-1.000 forint között. Olvasd el, hogy miért gondoljuk fontosnak, hogy erröl Te dönthess.

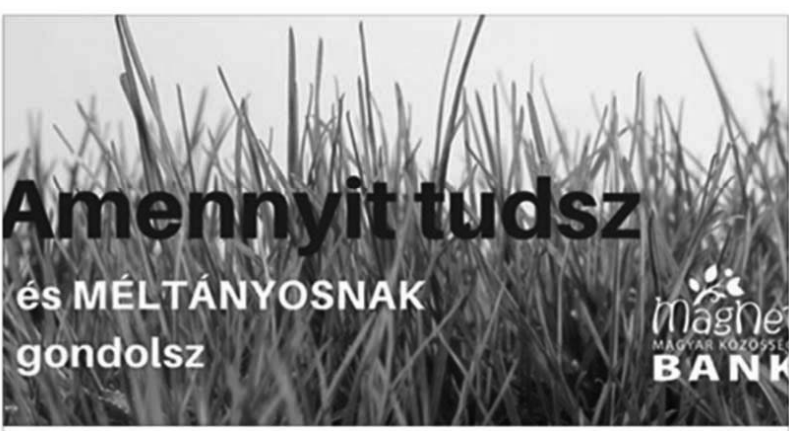

Becsületkasszás számlavezetés

Hisszük, hogy minden szolgáltatás, amely mögött emberi munka vagy technológiai fejlesztés áll, értékkel bír. Mindeközben azt is tudjuk, hogy anyag lehetőségeink nem egyformák.

MAGNETBANK.HU További információ

凹 Tetszik Q Hozzászólás $\Rightarrow$ Megosztás ㄱ. 